\title{
F-content variation in mammoth ivory from Aurignacian contexts: preservation, alteration, and implications for ivory-procurement strategies
}

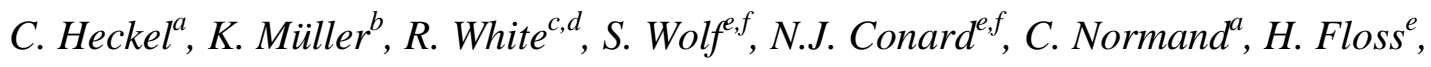 \\ I. Reiche R,g $^{\text {. }}$
}

a) Université de Toulouse II-Jean Jaurès, Laboratoire Travaux et Recherches Archéologiques sur la Culture, l'Espace et les Sociétés, CNRS UMR 5608, France

b) Universités Sorbonne-Université Paris IV, Laboratoire d'Archéologie Moléculaire et Structurale (LAMS), UMR 8220 CNRS, France

c) Center for the Study of Human Origins, Department of Anthropology, New York University, United States

d) UMI 3199 CNRS, New YorkUniversity, United States

e) Abteilung Ältere Urgeschichte und Quartärökologie, Institut für Ur- und Frühgeschichte und Archäologie des Mittelalters, Universität Tübingen, Germany

f) Senckenberg Center for Human Evolution and Paleoenvironment, Universität Tübingen, Germany

g) Rathgen Forschungslabor, Staatliche Museen zu Berlin, Stiftung Preußischer Kulturbesitz, Germany

Keywords: mammoth ivory; Aurignacian; diagenesis; fluorine; micro-PIXE/PIGE; Upper Paleolithic

\section{Abstract:}

This article presents the results of two series of micro-PIXE/PIGE analysis on mammoth ivory samples from four Aurignacian sites in France (Abri Castanet, Grotte d'Isturitz) and Germany (Hohle Fels, Vogelherd). Specifically, we report variation in ivory preservation as indicated by fluorine $(\mathrm{F})$ content and ratios of $\mathrm{MgO} / \mathrm{CaO}$ from Aurignacian horizons known to contain ivory industries. Though all samples derive from respectively homogenous sedimentary contexts, results show very different pattern of F-content variation among sites. F uptake in ivory is a more complex process than that observed for bone, and the structural/morphological reasons for this are explained. High-resolution 
data on the archaeological context of the samples from Abri Castanet also allows for examination of the effects of horizontal and vertical distribution on F-content and the sorting of F-content data by sedimentary unit. A definitive model for fluorine uptake during ivory diagenesis will require further investigation, but a close examination of the current data provides novel insight into processes of taphonomy and diagenesis in this exceptional and highly valued raw material, as well as further evidence to support regionally distinct strategies of ivory procurement in the Early Aurignacian. In combination with additional lines of faunal and archaeological evidence, it is demonstrated that ivory procurement in the Swabian Jura focused on fresh local sources of ivory, while procurement strategies in Northern Aquitaine focused on ivory collection from natural deposits of varying age.

\section{Introduction}

The use of ivory in the production of a wide range of tools and symbolic artefacts remains a hallmark of Early Upper Palaeolithic technology that currently has no correlate in previous periods of prehistory (Gaudzinski et al., 2005). With the arrival of H. sapiens in Eurasia, mammoth ivory assumed a place of great symbolic and economic importance in many societies. In addition to items of practical technological use (retouchers, smoothers, points, etc.), hundreds of personal ornaments (beads and pendants) were manufactured of mammoth ivory in the Early Aurignacian (ca 40-30 kya), as were musical instruments and dozens of three-dimensional sculptures of animals, humans, and therianthropes (Conard, 2009; Conard and Malina, 2008; Floss and Conard, 2010; Floss and Rouquerol, 2007; Hahn, 1986; White, 1993, 2007; Wolf, 2015). Some of these representational sculptures constitute the earliest such objects known in the world.

In spite of the significance of these artefacts, many details regarding the procurement, treatment, and use of mammoth ivory in the Early Upper Palaeolithic remain to be clarified. In the analysis of osseous archaeological materials, levels of geological Fluorine can be a source of useful information on preservation, taphonomy, and, with appropriate control of other variables, relative burial time (Gaschen et al., 2008; Goodrum and Olson, 2009; Lyman et al., 2012; Parker et al., 1974; Reiche, 2006). 
Following the development of radiocarbon dating, the focus in analyses of F-content has largely shifted to processes of diagenetic alteration rather than the potential for establishing chronologies. The vast majority of such research has been conducted on bone, and sometimes dentine. With some exceptions little chemical research has been undertaken on processes of diagenetic alteration of elephant (Albéric et al., 2014; Wang et al., 2007) and mammoth (Edwards et al., 2005; Heckel et al., 2014; Müller and Reiche, 2011; Sastri et al., 2013) ivory, which is a highly altered variation of dentine with specific chemical and structural characteristics. Non-destructive chemical analysis is a promising avenue of research in the study of ivory artefacts and is essential for determining "whether chemical indicators can be used as a source of information about diet, climate, genetics and dating or whether they record post-mortem transformation of original biominerals" (Guido et al., 2012: 180). As these issues are increasingly resolved, chemical analyses may offer unprecedented insight into patterns of ivory procurement, use, and exchange in the Palaeolithic.

Accurate interpretation of chemical data requires a better understanding of how diagenetic alteration occurs in ivory. Because $\mathrm{F}$ uptake in bone is a widespread, fairly consistent, and extensively-studied phenomenon, exploratory analyses of the same process in mammoth ivory are in progress, focusing on ivory samples from Aurignacian sites known for ivory exploitation. Previous research (Heckel et al., 2014) on F-content in archaeological ivory from Early Aurignacian deposits produced highly variable levels of $\mathrm{F}$ in some contexts, and highly uniform patterns in others, in spite of comparably homogenous sedimentary environments. We hypothesize that the observed variations in $\mathrm{F}$ content may be due to three potential factors, or a combination thereof: 1) the unique structural features of ivory tusks, 2) intersite and/or intrasite differences in sediment chemistry and/or hydrology, or 3) different approaches to ivory procurement in two major zones of ivory exploitation: Aquitaine (France) and the Swabian Jura (Germany), based on the analysis of 23 artefacts from four archaeological sites. In order to further investigate these hypotheses, and to contribute to an expanding body of data on ivory diagenesis in Early Upper Palaeolithic contexts, a second round of analyses was performed on an additional 19 samples from three Aurignacian sites. The current article 
combines some of the previously published results with the results of the new (previously unpublished) analyses.

Approaches to Aurignacian ivory technologies should be based on close examination of regionally-specific assemblages and should carefully consider evidence related to other areas of social, technological, and subsistence practices, to the extent that the archaeological evidence allows. In the evaluation of the three hypotheses described above, this study will assess the results of micro-PIXE/PIGE analysis in the context of additional data on site history, faunal records, subsistence practices, and technological observations made on the ivory assemblages. In the end, we assert that approaches to ivory procurement and processing varied regionally, with environment and with technological repertoires. A great deal remains to be explained with regard to early ivory artefacts and the exploitation of mammoth ivory in the Early Upper Palaeolithic, and onesize-fits-all models for the place of mammoths in Aurignacian economies should be replaced by data-driven, local models. This paper aims to contribute to the development of models of the latter variety, and to add to a growing body of data on the diagenetic alteration of archaeological ivories.

\section{Study sites: Geological and Archaeological Settings}

Three of the sites included in this paper (Abri Castanet, Vogelherd, and Hohle Fels) have yielded some of the most extensive assemblages of Early Aurignacian ivory artefacts known in Central and Western Europe, as well as a wealth of evidence for intensive onsite ivory processing. Ivory-work is also evidenced at the Grotte d'Isturitz, but to a more limited extent. The Grotte d'Isturitz presents the opportunity to investigate diagenetic differences among the three distinct phases of Aurignacian occupation evidenced at the site. A map of the study sites is presented in Figure 1. The basic archaeological and geological settings of the study sites are described below, as they are pertinent to the discussions of taphonomy and diagenesis that follow. Extensive presentation of the individual sites and their excavation histories are avoided for the sake of brevity, and references are provided to more in-depth coverage of these topics. For sites that have 
more than one series of radiometric dates, only the most recent are presented here. All dates are presented as uncalibrated radiocarbon dates.

\subsection{Grotte d'Isturitz}

The Grotte d'Isturitz is one of several karstic cavities formed by the Arberoue River in Lower Cretaceous (Aptian) limestone. The site straddles the communes of Saint-Martin de l'Arberoue and Isturitz, and lies in the foothills of the western Pyrenees approximately $30 \mathrm{~km}$ from the current Atlantic Coastline and $25 \mathrm{~km}$ from the nearest peaks of the Pyrenees proper. The tunnel forming the cave was separated by collapse into two primary chambers: the Salle Saint-Martin and the Salle d'Isturitz. Numerous early publications exist, and an overview of the site and its excavation history is provided by Normand and colleagues (Normand, 2007; Normand et al., 2007); an extensive discussion of the geomorphology and site-formation processes is provided by Lenoble (2005). The most recent excavations (1996-2008), from which the current study samples derive, were conducted in the Salle Saint-Martin under the direction of C. Normand. Of the sites included in this study, Isturitz is unique in having three technologically-distinct Aurignacian phases in preserved and well-documented stratigraphic sequence: Archaic Aurignacian (or Protoaurignacian), Early Aurignacian with Archaic Characteristics, and Early Aurignacian. The most recent radiocarbon assays on material from the site focused exclusively on level C4c4 (Early Aurignacian with Archaic Characteristics), and range from 40,200 \pm 3600 to $36,800 \pm 860 \mathrm{yrs}$ BP (Szmidt et al., 2010). No dates derived in the last decade are available for the other two Aurignacian deposits, but the $\mathrm{C} 4 \mathrm{c} 4$ dates serve as a terminus ante quem and terminus post quem for the lower and upper layers, respectively. In addition to Aurignacian deposits, the site has yielded abundant material attributed to the Magdalenian.

The ivory industry from Isturitz is relatively limited, and includes some ivory rods and fragments of bracelets, as well as a limited number of ivory pendants and basket-shaped beads (Heckel, 2015; White, 2007). A sizeable fragment of a tusk (ca. $25 \mathrm{~cm}$ in length) was also recovered from the Archaic Aurignacian layer, but was very poorly preserved. 


\subsection{Abri Castanet}

The site of Abri Castanet is one of several rock-shelters of archaeological significance carved into the Late Cretaceous (Coniacian-Santonian) limestone cliff-faces of the vallon of Castel-Merle (Sergeac, France) in the UNESCO World Heritage site of the Vézère Valley. The vallon itself is home to numerous intervisible rock-shelters containing Upper Palaeolithic deposits, including Abri Castanet, Abri Blanchard, Abri de la Souquette, Abri Labattut, and Abri Reverdit, among others. Several early publications on the site exist, and overviews of the early and recent research at the site are available in more recent publications (Mensan et al., 2012; White, 1989; White et al., 2012). The study material derives from recent excavations at the site, conducted from 1995-1998 under the direction of J. Pelegrin and R. White, and from 2005-2010 under the sole direction of R. White. The Early Aurignacian deposits at Abri Castanet lie directly on bedrock and were sealed after Aurignacian occupation by a roof collapse that landed in contact with the occupation surface. A series of sixteen radiocarbon dates obtained from material in the southern sector of the site (from which the study material derives) fall in a tight range of $33,250 \pm 500$ to $32,050 \pm 450$ (White et al., 2012).

The ivory industry at Abri Castanet is abundant, but limited almost exclusively to the production of basket-shaped beads and other ornamental artefacts (White, 1989, 2007; Heckel, 2015). Large specimens of ivory are unknown; the majority of ivory fragments are under $3 \mathrm{~cm}$ in greatest dimension, and the rare larger fragments do not exceed $15 \mathrm{~cm}$.

\subsection{Vogelherd Cave}

Vogelherd Cave (near Stetten, Germany) is located on a promontory overlooking the Lone Valley in the Swabian Jura, and was emptied entirely of archaeological deposits by G. Riek in 1931. The cave is a long, narrow chamber in Upper Jurassic (Malm) limestone with three entrances, and contained a thick archaeological sequence including four Middle Palaeolithic horizons, two Early Aurignacian horizons, one later Aurignacian 
horizon, two Magdalenian horizons, and some Holocene deposits. The archaeological sequence established by Riek has been somewhat revised based on reassessment of the collections, but has largely stood the test of time. Re-excavation of the backdirt was conducted from 2005 until 2012 under the direction of N. Conard, and has proven highly productive, revealing an abundant Palaeolithic industry as well as additional ivory figurines and fragments of figurines. An overview of the site and its excavation history is provided by Conard et al. (2003). A series of radiocarbon dates were obtained on material from the site, and the dates for the Aurignacian, based on eight samples, range from $35,810 \pm 710$ to $29,620 \pm 210$ (Conard and Bolus, 2003).

The Aurignacian ivory assemblage at Vogelherd Cave is by far one of the richest and most diverse in Europe. In terms of mammoth remains, the site is the richest of the Aurignacian period and one of the richest in central Europe. In addition to a range of tools, nearly twenty ivory figurines of animals (including fragments) have been identified and more may emerge as treatment of the fine-fraction from the recent re-excavation continues. More than 400 ivory beads and pendants have been recovered through the meticulous water-screening of the backdirt sediments (Wolf, 2015). The sorting of the fine-fraction is ongoing, and more such artifacts may emerge. Riek (1934) documented a stockpile of mammoth tusks and bones just inside the southwest entrance to the cave, as well as a 'bundle' of nearly two dozen ivory rods probably intended for bead manufacture (Niven, 2007). It remains a matter of debate whether the tusks and mammoth bones derived from hunting activities or were scavenged from local death sites. Production debris is difficult to sort by stratigraphic layer, but there is no doubt that extensive ivorywork occurred on-site.

\subsection{Hohle Fels Cave}

Hohle Fels Cave (near Schelklingen, Germany) is a large, dome-shaped carstic chamber in Upper Jurassic (Malm) limestone bordering the Ach Valley, which is adjacent to the Lone Valley in the Swabian Jura. It, too, has a long history of excavation (see Conard et al., 2015; Wolf, 2015). The site has been under nearly continuous excavation for almost 
30 years, under the direction of J. Hahn (1977-1979; 1987-1996) and then under the direction of N. Conard (1997-present). Like Vogelherd, the site has yielded abundant material culture in ivory, including the recently-discovered female figurine recovered at the base of the Aurignacian sequence (Conard, 2009). The stratigraphic sequence of the cave is very thick, and includes horizons attributed to the Middle Palaeolithic, Aurignacian, Gravettian, Magdalenian, and Holocene. The Aurignacian deposits are subdivided into six stratigraphic subunits; the study material derives from the two lowest (IV and V). Technologically, the entire sequence is attributed to the Early Aurignacian.

Like the Aurignacian ivory assemblage at Vogelherd, that at Hohle Fels is remarkably rich and diverse. It includes four ivory figurines, abundant ornaments, as well as various tools (such as chisels and points) and rich production debris (flakes, fragments, and splinters) (Wolf, 2015). In contrast to Vogelherd, mammoth bones are not numerous, and a greater degree of selection was exercised regarding elements transported back to the cave. Faunal analysis for the Aurignacian deposits is in progress, but aside from ivory, ribs are the predominant mammoth skeletal element at the site (Kitagawa et al., 2012)

\section{Materials and Methods}

The protocol of analysis for this study is identical that described in Heckel et al. (2014). Simultaneous Micro-PIXE/PIGE analyses were conducted over the course of two threeday sessions (one in 2013 and one in 2015) at the external micro-beam line of the $2 \mathrm{MV}$ tandem particle accelerator AGLAE at the Centre de Recherche et de Restauration des Musées de France (C2RMF) in Paris. The proton beam (3-MeV, ca. $50 \mu \mathrm{m}$ in diameter) was directed at the samples under atmospheric pressure with helium purging. Major, minor, and trace elements were measured. A minimum of three measurements were taken on each sample and the PIGE results for F content were obtained by calculating the net intensities of the emitted gamma-ray peaks and comparing them to those of reference samples containing F. Because the F-content values for the samples are very low overall (under $1 \mathrm{wt} \%$ ) and the reference sample contains $3 \mathrm{wt} \% \mathrm{~F}$, the exact values of $\mathrm{F}$ in the samples must be further refined. The results of most importance here are the levels of 
variation between samples, which are reliable due to the uniformity of the data collection and analysis on all samples. The high energy of the gamma rays is such that absorption effects can be ignored. For additional details please refer to Heckel et al. (2014).

Materials for the 2013 study are also described in Heckel et al. (2014). Those analyses revealed that the samples from Abri Castanet, which presents both the least complex stratigraphic sequence and the smallest range of radiocarbon dates, showed the most variation in terms of F-content in ivory samples. In contrast, artefacts from Vogelherd Cave, though recovered from the backdirt of Riek's 1931 excavations, showed very little variation in F-content. Because three-dimensional provenience information was recorded for all samples at Abri Castanet, it is possible to examine the effect of small-scale variation in sedimentary context on F-content. For the next set of analyses (in 2015), we chose to expand the dataset from Abri Castanet and to select samples from three contexts aimed at clarifying and contextualizing the variation observed in the samples from Abri Castanet. In this publication, the results from Grotte de la Verpillière I and II (Heckel et al., 2014) are excluded, as radiometric dating of the layers in question is currently under way, and will provide essential context for the further analysis of these results.

Table 1 lists all study materials, indicating site, material and object-type, and technocultural attribution. Three samples from Hohle Fels Cave provide a second sample-site in the Swabian Jura for comparison with Vogelherd Cave. At the Grotte d'Isturitz, three distinct phases of the Aurignacian have been documented. Six samples were selected from Isturitz, in order to examine variation between these stratigraphic units. Expanding the sample size from Abri Castanet was a priority, as determining the factors underlying the observed variation was of great interest. To this end, an additional 8 samples from Abri Castanet were included in the 2015 analyses.

The materials include ivory artefacts and production debris (including flakes, fragments, and artefacts interpreted as bead-production stages) as well as some artefacts in bone for comparison. Because a major aim of the study is to further archaeological understanding of ivory-acquisition practices, artefacts that showed extensive anthropogenic alteration, 
such as beads and bead-production stages, were preferentially selected. Regarding bone materials, a full comparative study was not possible at the time of analysis, but is planned for the near future. Three bone specimens were included in the sample series from Abri Castanet. Though limited, these results provide an important point of comparison for the ivory samples and will guide the design of future analyses. The majority of pieces from Abri Castanet are beads, which are under $7 \mathrm{~mm}$ in greatest dimension, and cylindrical bead-production stages, which are usually between 1.5 and $2.5 \mathrm{~cm}$ in length. Two barrelshaped beads and one basket-shaped bead from Isturitz were analysed, and one of the artefacts from Hohle Fels was a drop-shaped pendant. Nearly identical bandeaus (long, thin bands often perforated at one or both ends), one in bone (Cast17) and one in ivory (Cast20) presented the opportunity to compare two morphologically identical samples in two different materials.

Due to changes in temperature and humidity that often accompany artefact recovery, it is common for ivory artefacts to delaminate, or split along natural morphological interfaces (Heckel and Wolf, 2014; Poplin, 1995; Steguweit, 2015). This delamination presents an opportunity to take measurements at the interior of artefacts without causing additional damage to them. When this was not possible, measurements were taken at the artefact exterior. In all cases, zones indicating significant surface pollution from sediment (by the presence of elements such as $\mathrm{Si}$ and $\mathrm{Al}$ ) were avoided. A more in-depth assessment of the effect of measurement-location on F-content results is planned.

\section{Results and Discussion}

For all study samples $(\mathrm{n}=33)$, data on $\mathrm{F}$ content and on the preservation of biogenic $\mathrm{MgO} / \mathrm{CaO}$ was collected. While there is no direct correlation between F-content and $\mathrm{MgO} / \mathrm{CaO}$ preservation, the latter does serve as an additional indicator of the extent of alteration undergone by the samples, especially when comparing samples from a single context (see Müller and Reiche, 2011). Trace-element data was also collected and will be reported in a future publication. Because the results are heavily influenced by sediment chemistry and sediment hydrology, direct comparisons of absolute F-content cannot be made between sites. Levels of variation in F-content, however, can be productively 
compared between sites, and it is the differences in variation that is of most interest in the current discussion. Results are summarized in Section 4.1 of this paper, and possible explanations for the observed patterns are presented and assessed in Section 4.2.

\subsection{Results of F-content Analyses}

The study results are presented in Table 1, in which F-content is listed for each artefact, and in Figure 2, in which F-content is plotted against the ratio of preserved $\mathrm{MgO}$ to $\mathrm{CaO}$. Both $\mathrm{F}$ and $\mathrm{MgO} / \mathrm{CaO}$ are indicators of preservation state: geological $\mathrm{F}$ is absorbed from the sediment in the burial environment, and biogenic $\mathrm{MgO}$ leaches out of the ivory over time. $\mathrm{CaO}$ is often enriched through interaction with the depositional environment (Albéric et al., 2014). MgO dissipates quickly following deposition, except for contexts that favour their preservation, such as permafrost environments (Müller and Reiche, 2011). The $\mathrm{MgO} / \mathrm{CaO}$ ratio observed in the study samples are an additional indication of preservation state and are a useful point of comparison with the F-content in the samples. It must be kept in mind that preservation is not a proxy for absolute age, as a variety of factors can influence preservation of organic materials. As can be seen in Figure 2, there is not a strong correlation between $\mathrm{F}$ content and $\mathrm{MgO} / \mathrm{CaO}$ ratio.

Overall, the F-content and $\mathrm{MgO} / \mathrm{CaO}$ for the Vogelherd and Hohle Fels samples are the most consistent and uniform. F-content ranges from 0.04-0.1 wt\% at Vogelherd and only from 0.03-0.04 wt\% at Hohle Fels. This homogeneity indicates very similar states of preservation within these sites, and even between the sites there is relatively little variation. The samples from Vogelherd were collected from the backdirt of Riek's 1931 excavations, and are likely to have originated from different horizontal and vertical positions in the cave. Even so, the samples are relatively homogenous. The same is true of the samples from Hohle Fels, which derive from modern excavations and from a single stratigraphic unit.

A certain amount of variation was expected from the samples at Isturitz, as they were taken from three different occupation layers: the Archaic Aurignacian, the Early 
Aurignacian with Archaic Characteristics, and the Early Aurignacian. Two in two samples from the Archaic Aurignacian horizon at Isturitz, F-content was below the lowest level of detection. These two samples have been excluded for the time being, and further analysis of the data may allow us to be more precise. In Figure 3, the results from Isturitz are shown by chronological attribution. There is a clear pattern of $\mathrm{Mg} / \mathrm{CaO}$ preservation decreasing with the antiquity of the samples, but the F-content pattern is the opposite of what one would expect: the F-content is higher in the samples from the upper layers and lower in the samples from the lower layers. $\mathrm{Mg} / \mathrm{CaO}$ preservation follows expected patters, being higher in the upper layers and lower in the lower layers. In spite of the samples deriving from three different stratigraphic sequences, the overall dispersion remains much lower than that observed for Abri Castanet.

The greatest variation in F-content occurs very clearly at Abri Castanet, where it ranges from $0.13-0.7 \mathrm{wt} \%$ for all artefacts, and from $0.13-0.62 \mathrm{wt} \%$ for ivory artefacts alone. (Mean F-content value for all artefacts at Castanet is $0.44 \mathrm{wt} \%$, with a median of 0.45 wt $\%$ and a standard deviation of $0.14 \mathrm{wt} \%$.) While the bone specimens do show greater dispersion than the samples from Vogelherd and Hohle Fels, they show considerably less variation than the Castanet ivory samples, ranging only from $0.51-0.7 \mathrm{wt} \%$.

\subsection{Explanations for differences in F-content variation}

In this study, F-content data is not applied to relative chronology; the reliability of the technique has been demonstrated for bone but not for ivory. Our primary interest here is $\mathrm{F}$ and $\mathrm{MgO} / \mathrm{CaO}$ as indicators of preservation and the potential explanations for the variation in preservation observed, especially at Abri Castanet. The sections that follow examine the structural/morphological, depositional, and human-behavioural factors that may underlie the variability documented in this study. Each potential explanation is assessed in terms of the study result and of other lines of evidence as applicable. We find that the most likely explanation for the observed patterns of variation lies in regionallydifferent approaches to the acquisition of mammoth ivory, but do not rule out the influence of certain other factors. 
4.2.1 F uptake in ivory: tusk structure and morphology

Relative dating by F-content in bone is based on the observation that, in a context of homogenous sedimentary chemistry and hydrology, samples on similar skeletal parts from similar taxa can be sorted in terms of burial time based on levels of fluorine. Lyman (2012: 228) has expressed the process of $F$ uptake in terms of the equation: $F=f(S P, K$, $H, T$ ). In this formula, $\mathrm{F}$ content is a function of skeletal part (SP), sediment chemistry $(\mathrm{K})$, sediment hydrology $(\mathrm{H})$, and time in depositional environment $(\mathrm{T})$, holding constant the variables of $\mathrm{K}, \mathrm{H}$, and $\mathrm{T}$, examining ivory as a complex and internally variable skeletal part. Proboscidean tusk presents a number of structural differences when compared to bone skeletal elements, and even to cheek teeth (Heckel and Wolf, 2014; Virág, 2012).

In bone, the primary factors that facilitate diagenetic alteration are high organic content, porosity, and low crystallinity (Guido et al., 2012). Ivory is a dense material that naturally occurs in very large elements (tusks) that are highly resistant to fracture. Not only does it differ from bone in terms of porosity, density, and crystallinity, but these three factors can vary depending upon location within the tusk. Interpreting F-content in archaeological ivories requires an understanding of the structural and morphological factors that can complicate these data.

The organic content of bone and ivory are comparable (20-30 $\mathrm{wt} \%)$, but the porosity of ivory is much lower than that of bone. Chen et al. (2009) have established the porosity of elk antler as $9 \%$ and the porosity of bovid long bone as $5 \%$. The porosity of bone and antler is directly related to the porous Haversian system that allows for the circulation of blood and nutrients to living tissue. Ivory is not a living tissue, and is not supplied with blood or nutrients after its formation. The bulk of the material is perforated only by the miniscule (1-2 $\mu \mathrm{m}$ wide), undulating dentinal tubules that form the dentine. Not only are dentinal tubules narrow and undulating, but they are narrower toward the exterior surface of the tusk than at its interior (Viràg, 2012). The precise porosity of mammoth ivory is 
difficult to assess, as no completely unaltered specimens can be analyzed. The exact composition of the dentine that composes proboscidean tusks varies with species (Pearson, 2014: 51). The porosity of human dentine has been shown to range between $1.11 \%$ and 3.08\% (de Magalhaes et al., 2008). As ivory is solid dentine and mammoth ivory is composed of comparatively fine dentinal tubules, it can be presumed to be less porous than antler and bone. This is the primary reason that, while soaking bone and antler in water is an effective method of rendering it more pliable, soaking ivory has negligible effects on the material beyond the immediate exterior surface.

Both bone and ivory are made up of irregular plate-shaped nanocrystals of apatite, and are relatively low-crystallinity materials. The apatite crystals in proboscidean ivory are smaller than those in bone and in the dentine that forms the cheek-teeth of proboscideans (Su and Cui, 1997). Some studies have been conducted on changes in ivory crystallinity with prolonged burial time (Fan et al., 2006; Reiche et al., 2002; Wang et al., 2007). As in bone and other variations of dentine, deterioration of the organic phase and processes of recrystallization lead to an overall higher crystallinity in ancient ivories.

The effects of localized tusk morphology on F uptake processes need to be studied more extensively, but in the case of Vogelherd and Hohle Fels, specimens from different parts of tusks were analysed, and this had little effect on the F-content of the samples, which remains fairly uniform. It is difficult to ascertain with certainty the origin of smaller samples such as beads, but the Schreger lines and curvature confirm that the origin certain pieces derived from the exterior of the tusk ( $\mathrm{Vg} \mathrm{01})$ while others appear to derive

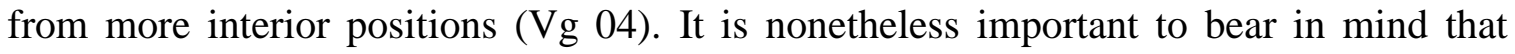
issues such as organic content, porosity, and crystallinity, tusk skeletal-part do not appear to introduce variability into our dataset, but must be assessed with larger sample sizes in the future.

\subsubsection{The effects of intersite sediment variation}


Another potential explanation for the differences observed is variation in F-content in the sediments at an intersite level. The results from Vogelherd, Hohle Fels, and Isturitz show uniformity, but also extremely low F-content values overall. The samples from Vogelherd, Hohle Fels, and Isturitz fall for the most part at or below this level, suggesting that F-content may have fallen since deposition, rather than rising. In two of the Isturitz samples (Ist 02 and Ist 03), the F-content fell below the threshold of detection (0.05 $\mathrm{wt} \%$ ). Both of these samples are from the lowest Aurignacian horizons of the site, and must be compared with bone samples from the same layer.

$\mathrm{F}$ is such a common element in sedimentary environments (and forms the highly stable fluorapatite when sediments meet water) that it seems highly unlikely that it would be absent from three of the four study sites. Additionally, in the cases of Vogelherd and Hohle Fels, $\mathrm{MgO} / \mathrm{CaO}$ further indicates uniformity in preservation state. In future analyses, examination of bone samples from the site of Hohle Fels as well as additional ivory samples representative of all six subunits within the Aurignacian stratigraphic unit will help to clarify some of these issues. Analysis of sediment samples is also possible for all sites but Vogelherd. At the moment, intersite variation in sedimentary F-content is not a satisfactory explanation for the differences seen between our samples sites. Even if Abri Castanet had overall higher levels of $\mathrm{F}$ in its sedimentary matrix, this would not explain the high level of dispersion seen in the data from the site. Similarly, the variation observed at Abri Castanet occurs in terms of both F-conent and $\mathrm{MgO} / \mathrm{CaO}$ preservation, indicating differences in overall preservation state of the samples.

\subsubsection{The effects of intrasite sedimentary variation}

Another potential source of variation in the Abri Castanet samples is small-scale variations in sedimentary chemistry and hydrology. Although such small-scale variations have been documented at Abri Castanet, they are subtle, and do not explain the F-content variation we observe, as will be demonstrated below. 
Of the study sites, Abri Castanet presents the least surface area and stratigraphic complexity. The sediments at Abri Castanet can be divided into three primary zones or groups based on shared characteristics and vertical and horizontal proximity. Zone 1 is characterized as lenses of silt-clay that show the influence of standing water and/or very weak water flow. Zone 2 is composed of the units that comprise the uppermost horizons of the archaeological layer, sandy sediments showing effects of weak water movement. Zone 3 is the richest in archaeological material, and extremely rich in burnt bone. In fact, in the fine-fractions of Zone 3 sediments, organic material (primarily burnt bone) was more abundant than were grains of sediment. In Figure 4, the F-content plot for Castanet is color-coded by sediment zone. It can be seen that no clear pattern of correlation of Fcontent with sediment zone emerges for Zones 2 and 3. Zone 1 shows the most uniform levels of F-content, which we posit may be an effect of the standing water or weak water flow mentioned above. Expansion of the dataset from Abri Castanet in combination with micromorphological analyses could provide insights into the effects of sediment hydrology on F uptake.

Horizontal distribution of F-content values is illustrated in Figure 5, in which the values for each sample are shown in the quarter square-meter from which the sample derives. The samples derive from a relatively small area: with one exception they were all recovered in a $3 \times 4$-meter zone surrounding the hearth feature (pictured in grey). Plotting F-content by elevation yielded an equally disorganized picture, with no close correlation between the two factors. Intersite variation in sedimentary matrices does not appear to explain the observed variation in the samples from Abri Castanet.

\subsubsection{The effect of ivory-procurement practices}

An additional factor that could introduce the observed variation in F-content and $\mathrm{MgO} / \mathrm{CaO}$ is the secondary deposition of ivories that were already of varying age when they arrived at Abri Castanet. As stated above, there remains debate about whether the ivory worked during the Aurignacian was "fresh" or highly deteriorated. This debate is complicated by the fact that the terms employed in these debates (fresh, fossil, subfossil, 
rotten), are highly qualitative and poorly defined. Furthermore, if preserved in favourable conditions such as permafrost, ivory can maintain many of its original mechanical properties and remain extremely strong and resistant to force (Heckel, 2009; Heckel and Wolf, 2014; Khlopachev and Girya, 2010). This paper is not the venue in which to refine the terminologies of ivory preservation, but it seems appropriate to briefly define certain terms as we will be employing them.

We use the term "fresh" to describe ivory that maintains much of its original physical properties, has undergone little chemical and physical alteration, and does not present delamination and splitting along the natural planes of weakness. This does not necessarily imply that the ivory was used immediately following the death of the animal, but that it was used shortly thereafter (a matter of decades, perhaps), or recovered in a state of excellent preservation from a permafrost environment. We avoid the term "fossil," as this would technically imply a complete replacement of the tusk with exogenous minerals. The term "subfossil" is employed in reference to ivory that has been more extensively physically and chemically altered through deposition and/or exposure.

Aurignacian peoples in areas actively inhabited by mammoths would have had access to fresh ivory (either through mammoth exploitation or through collection of mammoth death sites). As noted above, abundant presence of mammoths and active accumulation of mammoth bones and tusks are documented in the Swabian Jura (Niven, 2007). The hypothesis that fresh ivory was exploited in the Swabian Jura is supported by the archaeological record, in terms of the faunal record, technological observations, and the presence of large quantities of complete or near-complete tusks. The exploitation of fresh ivory could also explain the uniform states of preservation in samples from these sites. Steguweit (2015) has recently hypothesized that exclusively "rotten" ivory was exploited in the Early Upper Palaeolithic, because it would have been easier to exploit. This hypothesis is not well supported by the archaeological record at Hohle Fels or by the data presented in this paper. 
The extensive transformation of ivory from a "fresh" to a "rotten" state would take a few (if not tens of) thousands of years (see Müller and Reiche, 2011: 3240). Direct radiocarbon dating of an ivory specimen from layer $\mathrm{V}$ at Hohle Fels produced a date of $31,550 \pm 450 \mathrm{BP}$, which falls exactly in the range established by dates on other organic specimens (Wolf, 2015). Splitting "rotten" ivory (ivory that has lost most of its collagen and is soft/friable) would also produce relatively few splinters and flakes, which have been demonstrated to occur only by percussion and splitting of ivory in a relatively fresh or robust state (Heckel and Wolf, 2014). Several flakes showing features characteristic of the fracture of "fresh" ivory were recovered at Hohle Fels, in addition to hundreds of splinters, 160 of which were over $5 \mathrm{~mm}$ in length. In short, one of the authors (SW) has closely examined the entire ivory assemblage from the Aurignacian layers at Hohle Fels, and sees abundant evidence for the use of fresh ivory (Wolf, 2015). Similar characteristics were detected on several examples from Abri Castanet, and a more extensive discussion of the characteristics of fresh ivory fracture in reference to experimental and archaeological examples (from Hohle Fels and Abri Castanet) is provided in Heckel and Wolf (2014).

In addition, it has been demonstrated experimentally (Hein and Wehrberger, 2010) that fresh ivory could have been transformed with Aurignacian tools into pieces such as the famous Löwenmensch from Hohlenstein-Stadel (Swabian Jura). Hein reproduced the piece in fresh elephant ivory, and though it took more than 350 hours, it was accomplished only with Aurignacian stone tools and water to lubricate the exterior surface (which reduces friction and improves the effectiveness of the tools). This study stands to demonstrate that extensive alteration of the tusk is not strictly necessary for the production of known ivory figurines.

Another source of ivory, especially in areas in which mammoths were not abundant during the Early Aurignacian, would have been natural accumulations of ivory in small or large fragments. Haynes (1993) has documented such natural accumulations in modern African contexts. They occur in high frequencies during certain seasons and at certain locations, such as near sources of water, and include small flakes as well as large portions 
(sometimes $1 / 4$ to $1 / 2$ of a tusk) that are broken off during mating, fighting, and foraging activities. Such accumulations would have ostensibly been known to Aurignacian groups familiar with their landscapes, and would have provided a relatively convenient source of ivory. This ivory could have been several hundreds of years old, or even tens or hundreds of thousands of years old. Nonetheless, its accumulation and use at a site would introduce precisely the kind of variability in preservation states that we observe at Abri Castanet. As already demonstrated, this variability is not tied to vertical or horizontal distribution at the site, is not equally evident in the bone samples, and does not vary uniformly with sedimentary units. The most plausible explanation is that the ivory at the site was already in varying states of preservation when it arrived at there. Trace element data suggest the ivory was locally sourced, at least at the regional scale (Heckel et al., 2014).

Additional support for this argument lies in the faunal record of the region. For the Early Aurignacian, absolutely no postcranial skeletal elements of mammoth are documented in the region (Dordogne). Mammoths may have been intermittently present in this region during the Pleistocene, but there is no evidence that they were present during the occupation of Abri Castanet or that mammoth resources were actively exploited by Early Aurignacian peoples in southwestern France. As noted above, (Section 2.2), large pieces of ivory are rare in these contexts, and entire tusks entirely unknown. The geological history of the region makes it difficult or even impossible to either confirm or dispute that there was an abundance of ivory on the Aurignacian landscape. What is left of the record in Dordogne is primarily conserved in caves and rock shelters, while the modern-day landscape of rivers and plateaus has been considerably transformed by multiple events of erosion and, especially, substantial post-Holocene deposition of sediments. Such alteration of the landscape over time considerably complicates the study of ivoryprocurement practices and further underlines the need to examine multiple lines of evidence in comparative context in order to form a better understanding of these practices.

A final observation can be made on the drastic differences between the ivory industries at Abri Castanet and Hohle Fels. With the exception of some long, thin decorative artefacts 
known as "bandeaux" and a half-dozen pendants, the ivory industry at Abri Castanet is restricted to the production of very small $(5-7 \mathrm{~mm})$ ivory beads. As already noted, the ivory industry in the Swabian Jura is abundant, diverse, and includes artefacts in a wide range of sizes and shapes (Wolf, 2015). The differences in these assemblages may in part be due to local availability of ivory and distinct strategies of ivory procurement and transformation.

\subsubsection{Treatments of mammoth ivory in the Aurignacian}

Techniques for ivory-working in the Palaeolithic have been addressed by a number of scholars, with reference to both archaeological and experimental data (Christensen, 1999; Hahn et al., 1995; Khlopachev and Girya, 2010; Semenov, 1964). Various treatments to increase the workability of ivory tusks have been proposed, and these cannot be ruled out on the basis of our analyses or the archaeological record. Neither can they be confirmed. The substantial transformation of entire tusks from a state of freshness to a so-called "rotten" state (sensu Steguweit, 2015) in a matter of years, or even of a human generation, seems highly unlikely. Soaking in various solutions may have been effective for small pieces of ivory, but its effectiveness remains to be demonstrated at the scale of entire tusks outside of permafrost conditions.

Even in the light of experimental data, it is difficult to make generalizations about the treatment and processing of ivory during the Early Upper Palaeolithic across diverse contexts. Perhaps further experimental assays in combination with chemical analysis and scanning and transmission electron microscopy (SEM/TEM) investigation of alterations to the organic and inorganic matrices of ivory from experimental and archaeological would lend more clarity to the issue (see: Reiche et al., 2000; Su and Cui, 1997). Specifically, electron microscopy could provide visual evidence of material alterations to ivory due to either preparative treatments or diagenetic alteration. At the moment, we see little reason to conclude that the differences we observe were caused primarily by alterations or treatments of tusks or tusk fragments, but we must recognize that there may well be elements of Aurignacian ivory technologies that are not currently evident to us. 


\section{Conclusion}

Much remains to be determined about processes of $\mathrm{F}$ uptake in mammoth ivory and the application of F-content analysis to archaeological lines of inquiry. It is important to acknowledge the difference in the sample sizes employed: 20 samples (bone and ivory) from Abri Castanet compared to 4 samples (ivory) each from Hohle Fels and Vogelherd. Robust statistical analyses are not possible given these sample sizes, but the stark contrast between the two sample sets (Castanet on the one hand and Hohle Fels and Vogelherd on the other) seems highly unlikely to be the result of sampling bias, for reasons that have been addressed in the preceding discussion. In light of several additional lines of faunal and archaeological evidence, and the radiometric dates from Hohle Fels, we find the most plausible explanation of the data presented here to be regional differences in strategies of ivory procurement and use. In the Aurignacian of the Swabian Jura, postcranial mammoth remains at Vogelherd and Hohle Fels and the presence of entire tusks (Vogelherd) and extensive ivory debris (Hohle Fels) coincide with uniform preservation as evidenced by both F-content and ratios of $\mathrm{MgO} / \mathrm{CaO}$. High levels of variation in preservation, in terms of both $\mathrm{F}$-content and $\mathrm{MgO} / \mathrm{CaO}$ ratios, are documented at Abri Castanet, are greater in ivory samples than in bone samples, and do not vary in accordance with horizontal distribution, vertical distribution, or sedimentary unit. The faunal and archaeological records support a model of differential strategies of ivory procurement in these two regions during the Early Aurignacian, and the data from our recent analyses offer an additional line of evidence demonstrating variation in approaches to the acquisition and use of ivory.

These analyses are part of an on-going project focused on diagenesis of Early Upper Palaeolithic ivory, and future analyses will focus on expanding the dataset and on further investigating patterns and sources of variation in ivory preservation. In particular, we plan to add additional sites for comparative purposes, and to expand the sample sets from Hohle Fels and Isturitz, both to include bone and to include more ivory samples from the entire Aurignacian sequences at these sites in order to investigate diachronic variation at the site. Additionally, Micro-PIXE/PIGE analysis of directly-dated (radiocarbon dating) 
bone and ivory samples from the site of Germolles is under way, and promises to further clarify the patterns we have observed thus far. We anticipate that these future analyses will offer a more complex and more complete understanding of the phenomena underlying F-content variation in archaeological ivories. At present, we contend that the patterns we observe in F-content variation as presented above support many previous arguments for differences in ivory-procurement patterns in the Aurignacian.

\begin{tabular}{|c|c|c|c|c|}
\hline $\begin{array}{l}\text { Sampl } \\
\text { e } \\
\text { Numb } \\
\text { er }\end{array}$ & $\begin{array}{l}\text { Object } \\
\text { Description }\end{array}$ & $\begin{array}{l}\text { Recovery } \\
\text { Condition } \\
\mathrm{s}\end{array}$ & Attribution & F-Content \\
\hline Cast01 & ivory bead stage & modern & Early Aurignacian & 0.37 \\
\hline Cast02 & ivory bead & modern & Early Aurignacian & 0.39 \\
\hline Cast03 & ivory core & modern & Early Aurignacian & 0.43 \\
\hline Cast04 & $\begin{array}{l}\text { ivory flake } \\
\text { (article) }\end{array}$ & modern & Early Aurignacian & 0.49 \\
\hline Cast05 & ivory rod & modern & Early Aurignacian & 0.38 \\
\hline Cast06 & bone bead & modern & Early Aurignacian & 0.51 \\
\hline Cast07 & ivory bead stage & modern & Early Aurignacian & 0.45 \\
\hline Cast08 & ivory flake & modern & Early Aurignacian & 0.44 \\
\hline Cast09 & ivory fragment & modern & Early Aurignacian & 0.62 \\
\hline Cast10 & ivory bead & modern & Early Aurignacian & 0.32 \\
\hline Cast11 & ivory fragment & modern & Early Aurignacian & 0.27 \\
\hline Cast12 & ivory bead & modern & Early Aurignacian & 0.59 \\
\hline Cast13 & ivory bead stage & modern & Early Aurignacian & 0.34 \\
\hline Cast14 & ivory bead & modern & Early Aurignacian & 0.37 \\
\hline Cast15 & ivory bead stage & modern & Early Aurignacian & 0.13 \\
\hline Cast16 & bone fragment & modern & Early Aurignacian & 0.61 \\
\hline
\end{tabular}




\begin{tabular}{|l|l|l|l|l|}
\hline Cast17 & bone bandeau & modern & Early Aurignacian & 0.7 \\
\hline Cast18 & bone flake & modern & Early Aurignacian & 0.66 \\
\hline Cast20 & ivory bandeau & modern & Early Aurignacian & 0.45 \\
\hline Cast21 & ivory bead & modern & Early Aurignacian & 0.47 \\
\hline Ist01 & ivory bead & modern & Early Aurignacian & 0.19 \\
\hline Ist02 & ivory flake & modern & Archaic Aurignacian & $<L L O D$ \\
\hline Ist03 & ivory fragment & modern & Archaic Aurignacian & $<L L O D$ \\
\hline Ist04 & bead & modern & $\begin{array}{l}\text { Early Aurig. w/ Archaic } \\
\text { Character. }\end{array}$ & 0.1 \\
\hline Ist05 & ivory fragment & modern & Archaic Aurignacian & 0.03 \\
\hline Ist06 & ivory bead & modern & Early Aurignacian & 0.2 \\
\hline Vog01 & ivory fragment & pre- & Early Aurignacian & 0.06 \\
modern & $\begin{array}{l}\text { pre- } \\
\text { modern }\end{array}$ & Early Aurignacian & 0.07 \\
\hline Vog02 & ivory fragment & \begin{tabular}{l} 
\\
\hline Vog03
\end{tabular} & ivory bead & pre- \\
modern & Early Aurignacian & 0.04 \\
\hline Vog04 & ivory fragment & $\begin{array}{l}\text { pre- } \\
\text { modern }\end{array}$ & Early Aurignacian & 0.1 \\
\hline HoF01 & ivory rod & modern & Early Aurignacian & 0.03 \\
\hline HoF02 & ivory pendant & modern & Early Aurignacian & 0.04 \\
\hline HoF03 & ivory fragment & modern & Early Aurignacian & 0.03 \\
\hline
\end{tabular}

Table 1: List of samples by sample number, indicating artefact type, recovery conditions, chronocultural attribution, and the results of F-content analysis. (Cast=Castanet, Ist=Isturitz, Vog=Vogelherd, HoF=Hohle Fels.) Ist 02 and Ist03 are listed, but their Fcontent was below the lowest level of detection (LLOD).

\section{Acknowledgments:}


The analyses reported in this paper were performed at the AGLAE facility at the Centre de Recherche et de Restauration des Musées de France, with support from the European CHARISMA (Cultural Heritage Advanced Research Infrastructures-Synergy for a Multidisciplinary Approach to Conservation/Restoriation) program co-funded by the European Commission within the action 'Research Infrastructures' of the 'Capacities' Programme GA No. FP7-228330 as part of the project "Taphonomic alteration and traceelement preservation in mammoth ivory from Early Upper Palaeolithic contexts." Many thanks are due to the members of the NEW AGLAE laboratory for their assistance during the analyses: Claire Pacheco, Laurent Pichon, Quentin Lemasson, and Brice Moignard. This project would not have been possible without their support and participation. NEW AGLAE is a Féderation de Recherche (FR3506) project jointly supported by the CNRS and the Ministère de la Culture et de la Communication in France.

Excavations at Abri Castanet have been supported by the National Science Foundation (United States), the Partner University Fund, DRAC-Aquitaine, the Leakey Foundation, the Reed Foundation, the Rock Foundation, CIRHUS (CNRS-NYU) and the Theodore Dubin Foundation. Excavations at Isturitz would not have been possible without the support of DRAC-Aquitaine, Conseil Général des Pyrénées-Atlantiques, SARL Grottes d'Isturitz et d'Oxocelhaya, Société d'Etudes Basques Eusko Ikaskuntza, and Laboratoire TRACES CNRS-UMR 5608, and of the site owner, Joëlle Darricau. Excavations at Hohle Fels and at Vogelherd have been conducted with the support of the Deutsche Forschungsgemeinschaft, the University of Tübingen, the Heidelberger Akademie der Wissenschaften, the Landesamt für Denkmalpflege Baden-Württemberg, the Alb-DonauKreis, Heidelberg Cement, the Museumsgesellschaft Schelklingen and the Gesellschaft für Urgeschichte. C. Heckel's research in France was funded by a post-doctoral fellowship from the Fyssen Foundation.

\section{References}

Albéric, M., Gourrier, A., Müller, K., Zizak, I., Wagermaier, W., Fratzl, P., Reiche, I., 2014. Early diagenesis of elephant tusk in marine environment. Palaeogeography, Palaeoclimatology, Palaeoecology 416, 120-132. 
Chen, P.Y., Stokes, A.G., McKittrick, J., 2009. Comparison of the structure and mechanical properties of bovine femur bone and antler of the North American elk (Cervus elaphus canadensis). Acta Biomaterialia 5, 693-706.

Christensen, M., 1999. Technologie de l'ivoire au Paléolithique supérieur: caractérisation physico-chimique du matériau et analyse fonctionnelle des outils de transformation. British Archaeological Reports.

Conard, N.J., 2009. A female figurine from the basal Aurignacian of Hohle Fels Cave in southwestern Germany. Nature 459, 248-252.

Conard, N.J., Bolus, M., 2003. Radiocarbon dating the appearance of modern humans and timing of cultural innovations in Europe: new results and new challenges. Journal of Human Evolution 44, 331-371.

Conard, N.J., Bolus, M., Dutkiewicz, E., Wolf, S., 2015. Eiszeitarchäologie auf der Schwäbischen Alb: die Fudnstellen im Ach- und Lonetal und ihrer Umgebung. Kerns Verlag, Tübingen.

Conard, N.J., Malina, M., 2008. New evidence for the origins of music from the caves of the Swabian Jura. AA Both, R. Eichmann, E. Hickmann \& L.-CH. Koch (Eds.). OrientArchäologie 22, 13-22.

Conard, N.J., Niven, L.B., Mueller, K., Stuart, A.J., 2003. The chronostratigraphy of the Upper Paleolithic deposits at Vogelherd. Mitteilungen der Gesellschaft für Urgeschichte $12,73-86$.

de Magalhaes, M.F., Ferreira, R.A.N., Grossi, P.A., de Andrade, R.M., 2008. Measurement of thermophysical properties of human dentin: effect of open porosity. Journal of dentistry 36, 588-594.

Edwards, H.G.M., Villar, S.E.J., Hassan, N.F.N., Arya, N., O'Connor, S., Charlton, D.M., 2005. Ancient biodeterioration: an FT-Raman spectroscopic study of mammoth and elephant ivory. Analytical and bioanalytical chemistry 383, 713-720.

Fan, H., Wang, L., Deng, M., Ye, Q., Dan, H., Sun, J., Song, Y., Yang, Y., 2006. Phases and Crystalline Characteristics in Ancient Ivory Unearthed from Sanxingdui and Jinsha. Journal-Chinese Ceramic Society 34, 744.

Floss, H., Conard, N.J., 2010. L'art mobilier du Jura souabe, in: Otte, M. (Ed.), Les Aurignaciens. Éditions Errance, pp. 201-214. 
Floss, H., Rouquerol, N., 2007. Les chemins de l'art aurignacien en Europe-Das Aurignacien und die Anfänge der Kunst in Europa, Colloque International, Aurignac 2005. Éditions de Musée-forum d'Aurignac, Aurignac.

Gaschen, A.-M., Döbeli, M., Markwitz, A., Barry, B., Ulrich-Bochsler, S., Krähenbühl, U., 2008. Restrictions on fluorine depth profiling for exposure age dating in archaeological bones. Journal of Archaeological Science 35, 535-552.

Gaudzinski, S., Turner, E., Anzidei, A., Àlvarez-Fernández, E., Arroyo-Cabrales, J., Cinq-Mars, J., Dobosi, V., Hannus, A., Johnson, E., Münzel, S., 2005. The use of Proboscidean remains in every-day Palaeolithic life. Quaternary International 126, 179194.

Goodrum, M.R., Olson, C., 2009. The quest for an absolute chronology in human prehistory: anthropologists, chemists and the fluorine dating method in palaeoanthropology. The British journal for the history of science 42, 95-114.

Guido, A., Marra, A.C., Mastandrea, A., Tosti, F., Russo, F., 2012. Micromorphological, geochemical, and diagenetic characterization of sirenian ribs preserved in the Late Miocene paleontological site of Cessaniti (southern Calabria, Italy). Facies 58, 179-190.

Hahn, J., 1986. Kraft und Agression. Die Botschaft der Eiszeitkunst im Aurignacien Süddeutschlands? Archaeologica Venatoria, Tübingen.

Hahn, J., Menu, M., Taborin, P., Walter, P., Widemann, F., 1995. Le travail et l'usage de l'ivoire au paléolithique supérieur. Table ronde de Ravello (29-31 Mai 1992) Instituto Poligrafico e Zecca dello Stato, Rome.

Haynes, G., 1993. Mammoths, mastodonts, and elephants: biology, behavior and the fossil record. Cambridge University Press.

Heckel, C., 2009. Physical characteristics of mammoth ivory and their implications for ivory work in the Upper Paleolithic. Mitteilungen der Gesellschaft für Urgeschichte 18, 71.

Heckel, C., 2015. Production Organization in the Early Upper Paleolithic: Ivory tools and ornaments of the French Aurignacian, Department of Anthropology. New York University (unpublished $\mathrm{PhD}$ thesis).

Heckel, C., Müller, K., White, R., Floss, H., Conard, N., Reiche, I., 2014. MicroPIXE/PIGE analysis of Palaeolithic mammoth ivory: potential chemical markers of 
provenance and relative dating. Palaeogeography, Palaeoclimatology, Palaeoecology 216, 133-141.

Heckel, C.E., Wolf, S., 2014. Ivory debitage by fracture in the Aurignacian: experimental and archaeological examples. Journal of Archaeological Science 42, 1-14.

Hein, W., Wehrberger, K., 2010. Löwenmensch 2.0. Nachbildung der Elfenbeinstatuette aus der Hohlestein-Stadel-Höhle mit authentischen Werkzeugen. Experimentelle Archäologie in Europa, Bilanz 2020, 47-55.

Khlopachev, G.A., Girya, E.Y., 2010. Secrets of ancient carvers of Eastern Europe and Siberia. Treatment techniques of ivory and reindeer antler in the Stone Age. Based on archaeological and experimental data. Nauka, St. Petersburg.

Kitagawa, K., Krönneck, P., Conard, N.J., Münzel, S.C., 2012. Exploring cave use and exploitation among cave bears, carnivores and hominins in the Swabian Jura, Germany. Journal of Taphonomy 10.

Lenoble, A., 2005. Ruissellement et formation des sites préhistoriques: référentiel actualiste et exemples d'application au fossile.

Lyman, R.L., Rosania, C.N., Boulanger, M.T., 2012. Comparison of fluoride and direct AMS radiocarbon dating of black bear bone from Lawson Cave, Missouri. Journal of Field Archaeology 37, 226-237.

Mensan, R., Bourrillon, R., Cretin, C., White, R., Gardère, P., Chiotti, L., Sisk, M., Clark, A., Higham, T., Tartar, É., 2012. Une nouvelle découverte d'art pariétal aurignacien in situ à l'abri Castanet (Dordogne, France): contexte et datation. PALEO. Revue d'archéologie préhistorique, 171-188.

Müller, K., Reiche, I., 2011. Differentiation of archaeological ivory and bone materials by micro-PIXE/PIGE with emphasis on two Upper Palaeolithic key sites: Abri Pataud and Isturitz, France. Journal of Archaeological Science 38, 3234-3243.

Niven, L., 2007. From carcass to cave: Large mammal exploitation during the Aurignacian at Vogelherd, Germany. Journal of human evolution 53, 362-382.

Normand, C., 2007. Les Aurignaciens de la Grotte d'Isturitz, in: Floss, H., Roquerol, N. (Eds.), Les Chemins de l'Art Aurignacien en Europe. Éditions Musée-Forum, Aurignac.

Normand, C., Sophie, A., Costamagno, S., Diot, M.-F., Henry-Gambier, D., Goutas, N., Laroulandie, V., Lenoble, A., O'Farrell, M., Rendu, W., 2007. Nouvelles données sur la 
séquence aurignacienne de la grotte d'Isturitz (communes d'Isturitz et de Saint-Martind'Arberoue. Pyrénées-Atlantiques). Un siècle de construction du discours scientifique en Préhistoire, vol. III"... Aux conceptions d'aujourd'hui", Actes du Congrès Préhistorique de France, XXVIe session, Congrès du Centenaire, 21-25 septembre 2004, Avignon., 277-293.

Parker, R.B., Murphy, J., Toots, H., 1974. Fluorine in fossilized bone and tooth: distribution among skeletal tissues. Archaeometry 16, 98-102.

Pearson, C., 2014. Conservation of marine archaeological objects. Elsevier.

Poplin, F., 1995. Délitage et débitage dans le travail de l'ivoire vrai sur des exemples du début du Paléolithique supérieur. Le travail et l'usage de l'ivoire au Paléolithique supérieur, Actes de la Table Ronde de Ravello, 29-31.

Reiche, I., 2006. Fluorine and its relevance for archaeological studies. Advances in Fluorine Science 2, 253-283.

Reiche, I., Vignaud, C., Calligaro, T., Salomon, J., Menu, M., 2000. Comparative analysis of odontolite, heated fossil ivory and blue fluorapatite by PIXE/PIGE and TEM. Nuclear Instruments and Methods in Physics Research Section B: Beam Interactions with Materials and Atoms 161, 737-742.

Reiche, I., Vignaud, C., Menu, M., 2002. The crystallinity of ancient bone and dentine: new insights by transmission electron microscopy. Archaeometry 44, 447-459.

Riek, G., 1934. Die Eiszeitjägerstation am Vogelherd im Lontal. Academischer Verlagsbuchhandlung, Tübingen.

Sastri, C.S., Banerjee, A., Sauvage, T., Courtois, B., Schuhmacher, T., 2013. Fluorine determination in different types of ivory by PIGE technique. Journal of Radioanalytical and Nuclear Chemistry 298, 311-315.

Semenov, S.A., 1964. Prehistoric Technology; an Experimental Study of the Oldest Tools and Artefacts From Traces of Manufacture and Wear. Cory, Adams \&Mackay, London.

Steguweit, L., 2015. Rotten ivory as raw material source in European Upper Palaeolithic. Quaternary International 361, 313-318.

Su, X.W., Cui, F.Z., 1997. Direct observations on apatite crystals in ivory. Materials Science Letters 16, 19-29. 
Szmidt, C., Normand, C., Burr, G.S., Hodgins, G.W.L., LaMotta, S., 2010. AMS 14C dating the Protoaurignacian/Early Aurignacian of Isturitz, France. Implications for Neanderthal-modern human interaction and the timing of technical and cultural innovations in Europe. Journal of Archaeological Science 37, 758-768.

Virág, A., 2012. Histogenesis of the unique morphology of proboscidean ivory. Journal of morphology 273, 1406-1423.

Wang, L., Fan, H., Liu, J., Dan, H., Ye, Q., Deng, M., 2007. Infrared spectroscopic study of modern and ancient ivory from sites at Jinsha and Sanxingdui, China. Mineralogical Magazine 71, 509-518.

White, R., 1989. Production complexity and standardization in early Aurignacian bead and pendant manufacture: Evolutionary implications, in: Mellars, P., Stringer, C. (Eds.), The human revolution: behavioural and biological perspectives on the origins of modern humans. Edinburgh University Press, Edinburgh, pp. 366-390.

White, R., 1993. Technological and social dimensions of "Aurignacian-age" body ornaments across Europe, Before Lascaux. CRC Press, Boca Raton, FL, pp. 277-299.

White, R., 2007. Systems of personal ornamentation in the Early Upper Paleolithic: methodological challenges and new observations, in: Mellars, P., Boyle, K., Bar-Yosef, O., Stringer, C. (Eds.), Rethinking the Human Revolution: new behavioural and biological perspectives on the origin and dispersal of modern humans. McDonald Institute for Archaeological Research, Cambridge, UK, pp. 287-302.

White, R., Mensan, R., Bourrillon, R., Cretin, C., Higham, T.F.G., Clark, A.E., Sisk, M.L., Tartar, E., Gardère, P., Goldberg, P., 2012. Context and dating of Aurignacian vulvar representations from Abri Castanet, France. Proceedings of the National Academy of Sciences 109, 8450-8455.

Wolf, S., 2015. Schmuckstücke - Die Elfenbeinbearbeitung im Schwäbischen Aurignacien. Kerns Verlag, Tübingen. 


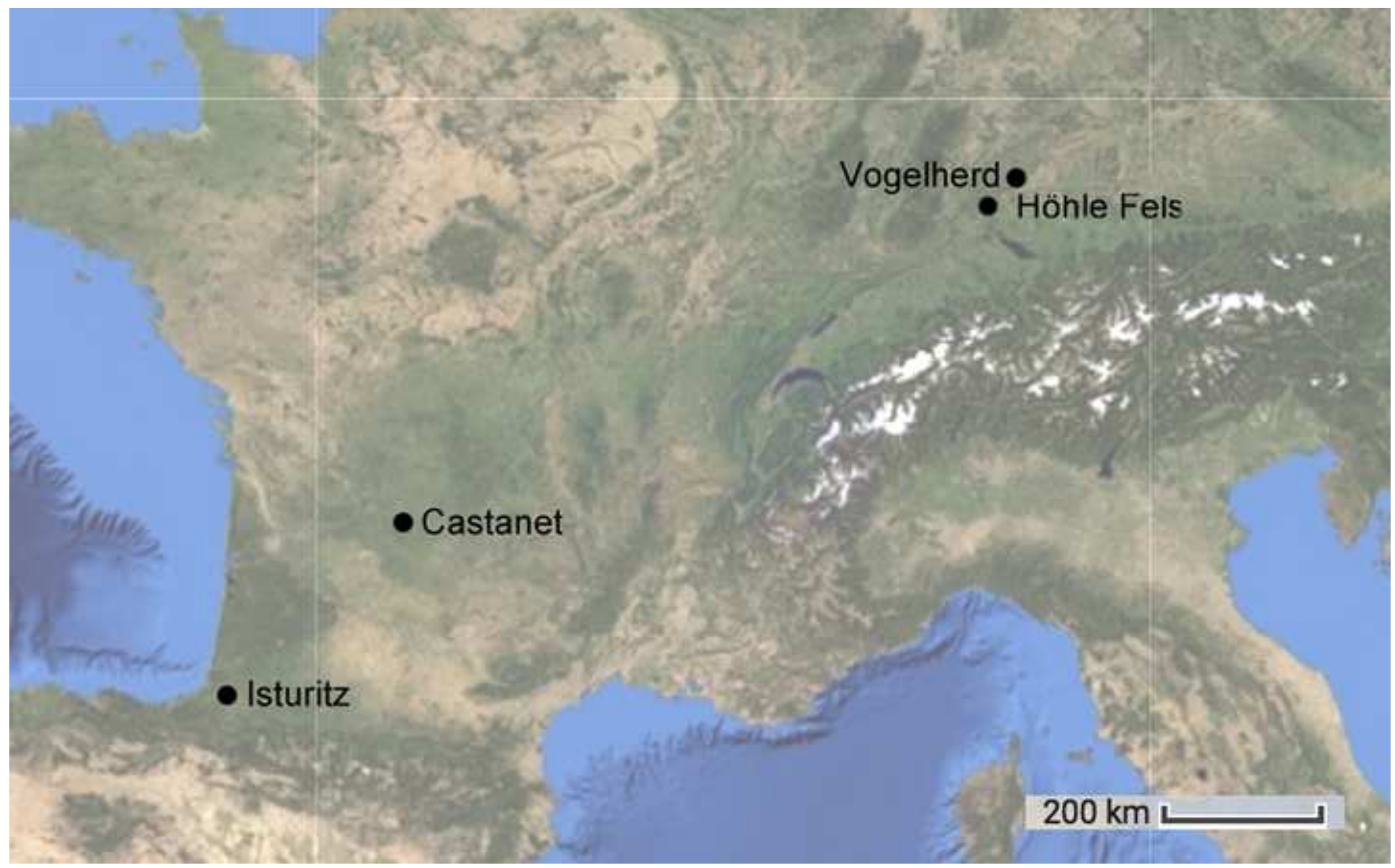




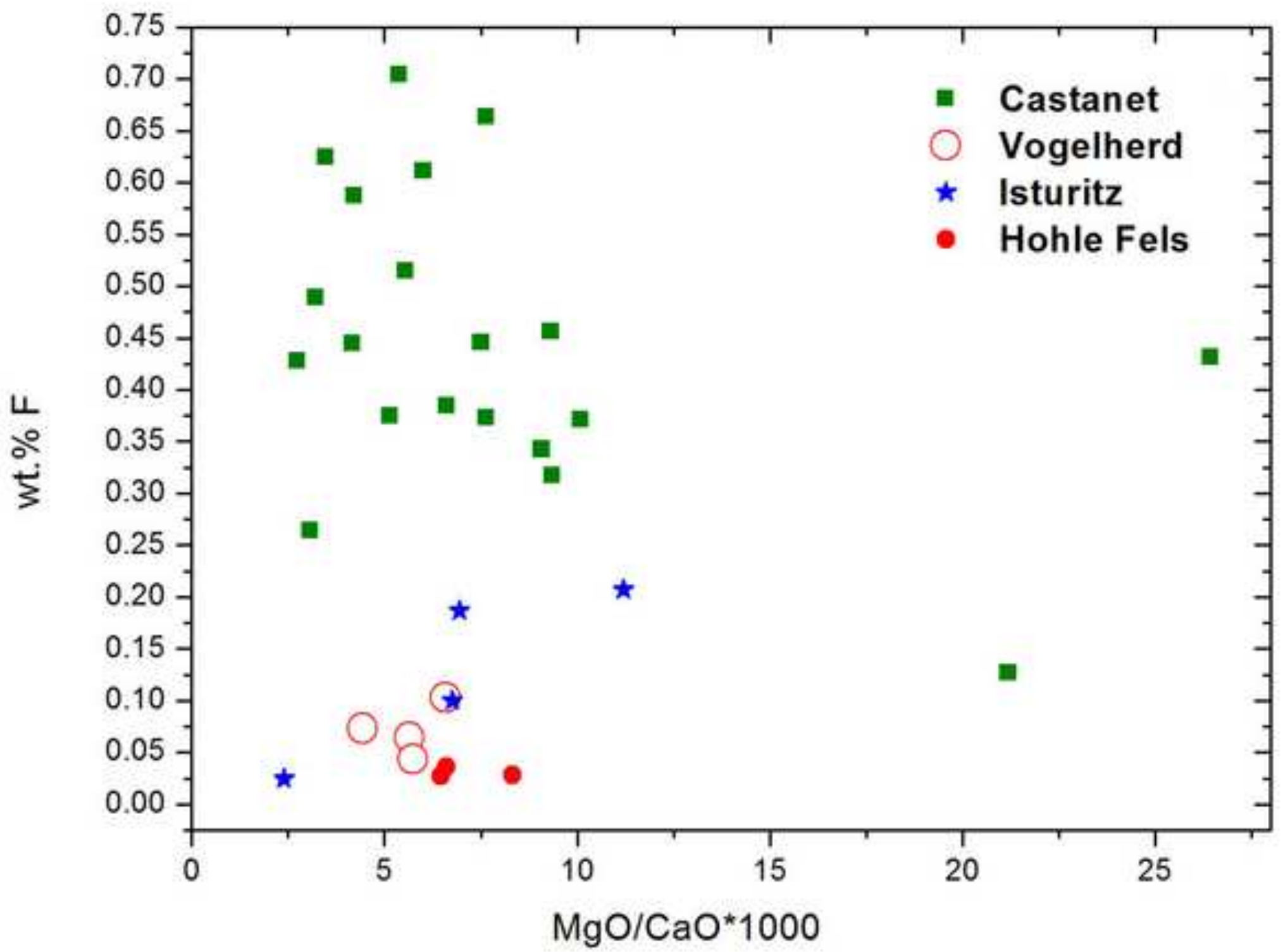




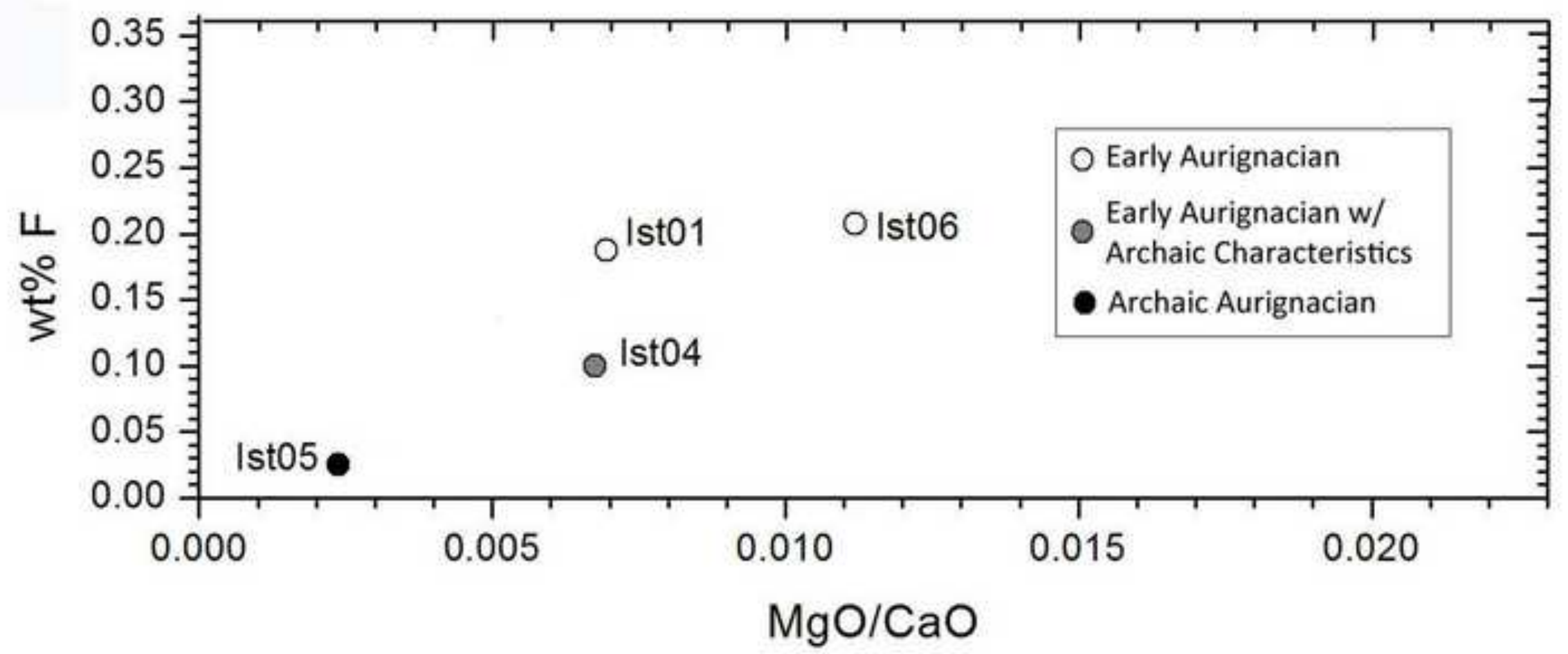




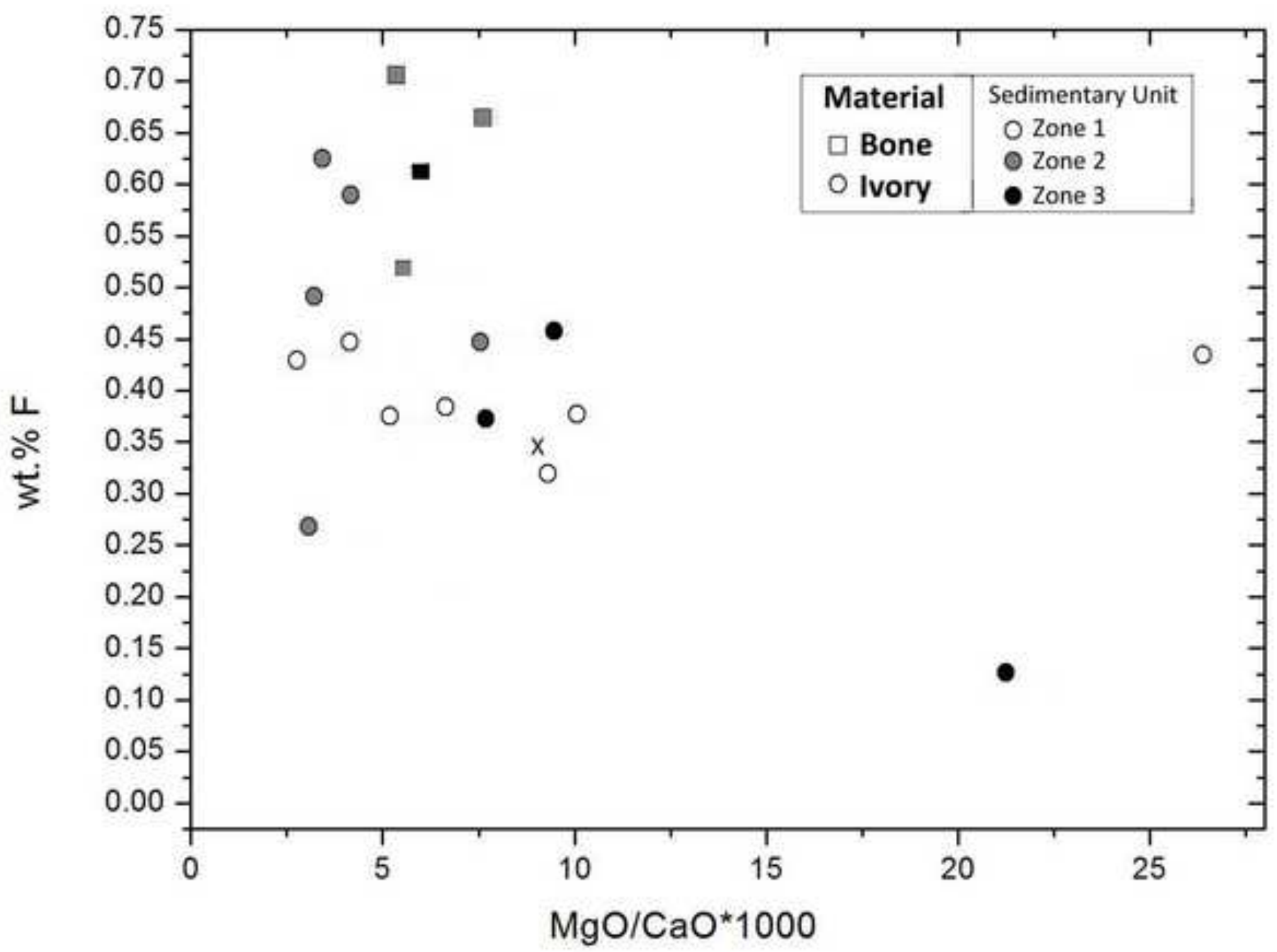




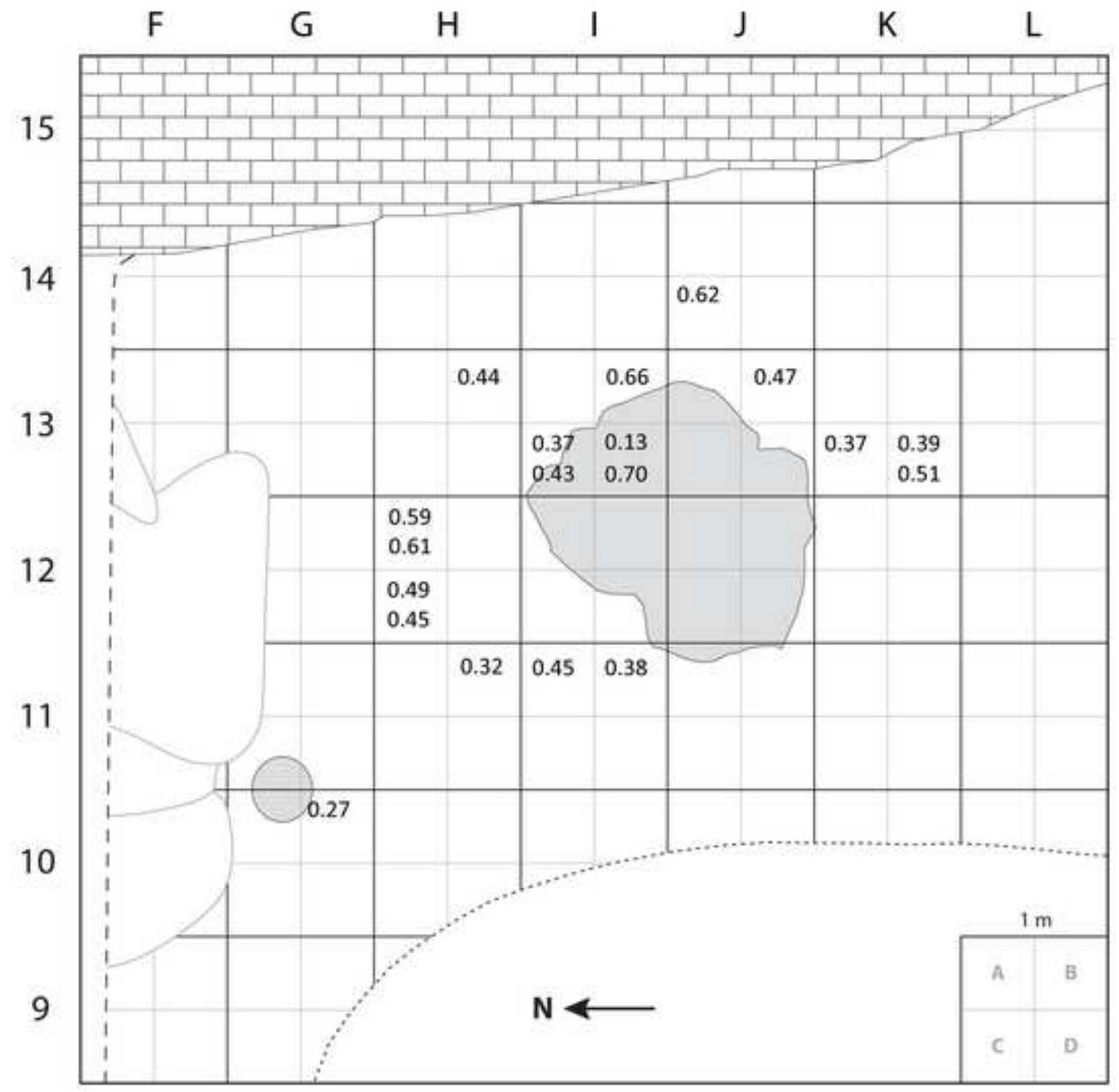

Legend

Limestone blocks

..... Limit of excavation

$\square$ Cliff face 
Figure Captions Heckel et al

(Hard Animal Materials UISPP)

Figure 1: Map of study sites.

Figure 2: F content (wt\%) and $\mathrm{MgO} / \mathrm{CaO}(* 1000)$ for the study samples from Abri Castanet $(n=20)$, Grotte d'Isturitz $(n=6)$, Vogelherd Cave $(n=4)$, and Hohle Fels Cave $(n=3)$.

Figure 3: Detail of results from Isturitz, with samples labelled by phase of the Aurigancian. These phases are defined by technological traits, but also represent discrete stratigraphic units at the site (Normand, 2007). Even with three different layers spanning several thousands of years, these samples show little variation in $\mathrm{F}$ content compared to the samples from Abri Castanet.

Figure 4: Detail of the results from Abri Castanet, with sedimentary units grouped by zone. While artefacts from Zone 2 generally show higher levels of $F$ than those from Zone 1 , there is no clear relationship between F-content and sedimentary unit. Artefacts from Zone 3 are very highly dispersed. Descriptions of these sedimentary zones are provided in the text (Section 5.2). Here, it can also be seen that less variation is evident in the bone samples than in the ivory samples. The point marked by an " $X$ " is an artefact recovered from backdirt for which no sedimentary data is available.

Figure 5: Horizontal distribution of F-values by quarter-square-meter. It is clear from this image that F-content is not explained by horizontal distribution, but varies across the site. This image also illustrates the limited surface area of the southern sector of the Castanet excavations. 